\title{
Abandoning Refugees? An Analysis of the Legal Framework Governing Non-compliant Claimants in Canada
}

\author{
MARTIN JONES
}

\begin{abstract}
The refugee status determination ( $R S D)$ process in Canada, like the RSD processes of other states, currently rejects one in fifteen refugee claims based upon the non-compliance of refugee claimants with the rules of the process. Most commonly this is due to a claimant's failure to provide requested information or his or her failure to attend a scheduled hearing. These "abandonment" decisions result in the expedited removal of claimants without access to further review. Despite the drastic consequences of such decisions, the framework within which they are made neither has been comprehensively outlined nor has its application been catalogued, which is the aim of this paper. It argues that while the formal provisions of the domestic framework are both inconsistent with international law and in excess of the delegated authority through which it is constructed, the Court's application of the framework has been generous to refugee claimants.
\end{abstract}

\section{Résumé}

Le processus de détermination du statut de réfugié (DSR) au Canada, tout comme les processus de DSR d’autres états, rejette actuellement une revendication du statut de réfugié sur quinze, basé sur le non-respect des règlements du processus par les demandeurs du statut de réfugié. Le plus souvent, la raison est qu'un demandeur n'a pas soumis les informations demandées, ou ne sest pas présenté à une audience régulière. Ces décisions pour " abandon" donnent lieu à un processus accéléré de renvoi des demandeurs sans accès supplémentaire à un réexamen. Malgré les conséquences drastiques de telles décisions, le cadre dans lequel elles sont faites nia pas été suffisamment élaboré dans tous ses détails, ni leur application cataloguée, ce qui est l'objectif de cet article.
The most likely outcome of a refugee claim in Canada is acceptance. However, another highly possible outcome is abandonment. In the first half of 2008, out of a total of 8,311 decisions made in refugee claims, 535 (or 6 per cent) were decisions to declare a refugee claim to have been abandoned. ${ }^{1}$ In some offices of the Immigration and Refugee Board (the Board), abandonment decisions account for one-tenth of decisions rendered. ${ }^{2}$ Abandonment can be the outcome of an even larger percentage of refugee claims in Canada from certain countries of origin. ${ }^{3}$ Even countries of origin with very high rates of acceptance can be plagued by significant numbers (both absolutely and relatively) of abandoned refugee claims. Furthermore, the issue of abandonment is not particular to Canada. In recent years in the United Kingdom refusals because of "non-compliance" have accounted for a similar proportion of decisions rendered. ${ }^{4}$ In 2008 , the practice of Greece in declaring as "interrupted" very large numbers of cases attracted condemnation by the United Nations High Commissioner for Refugees (UNHCR). ${ }^{5}$

It has been suggested that these high rates of abandonment decisions raise concerns regarding the population of refugee claimants in Canada (and elsewhere). These concerns have commonly prompted the drafting of provisions allowing for the expedited removal of individuals who abandon their requests for asylum. Such provisions simply raise the ante for the refugee claimant and underscore the potentially catastrophic consequences of an abandonment decision. Yet despite accounting for a sizable percentage of refugee claim outcomes, the law governing the abandonment of refugee claims in Canada (and elsewhere) has not been the object of study. The purpose of this paper is to explore the legal frameworks which govern the manner in which these refugee claimants are dealt with by the administrative tribunals and courts of Canada charged with deciding their cases. The non-compliance of such claimants with the administrative machinery used to determine their worthiness for protection 
poses a conundrum: to what extent is compliance with the procedures of the country of asylum required in order to be entitled to its protection?

The answer to this question must be discerned within the bounds of the legal frameworks governing abandonment decisions, both international and domestic. The latter largely restrict abandonment decisions to situations where a claimant has failed to provide required information or to attend his or her hearing before the decision maker. Unfortunately, in determining whether either of these circumstances has occurred the latter domestic framework in significant ways is inconsistent with Canada's international obligations and its own schema of delegated authority. However, while the judiciary have failed to explicitly address these failings in the domestic frameworks, their decisions have read into the framework a requirement of intention that in many ways implicitly addresses the gaps of the domestic framework. To answer the question posed earlier, compliance with the procedures of the country of asylum is only required insofar as it is an indication of a continuous intention to seek the protection of Canada.

This article will begin by outlining the legal framework which governs decisions to abandon refugee claims. There are both international law and international practice that are relevant to determining the proper process that should be followed. In addition, Canada's legislation governing refugee protection, and its delegated legislation, provide limits on the reasons for and methods through which a claim can be declared abandoned. After establishing and critiquing the legal framework, the article will review its application by Canadian tribunals with a view to indicating the specific deficiencies in the legal framework that the jurisprudence has filled.

\section{Legal Framework}

As a term, "refugee status determination" (RSD) is somewhat misleading; the process of RSD does not "fix conclusively or authoritatively" (determine) the status of a refugee claimant. At international law, it is well established that refugee status exists before any status determination conducted by a state party to the Convention relating to the Status of Refugees (the Refugee Convention $)^{6}$ or the office of the UNHCR. ${ }^{7}$ RSD, through its process of gathering and interrogating information about the refugee claimant's situation in his or her country of origin, simply "recognizes" the pre-existing and independent status (or lack thereof) of the claimant. Logically then the status of an individual at international law persists regardless of whether a state or UNHCR in fact recognizes the "true" status of the claimant-or for that matter whether or not the refugee assists the state in recognizing his or her true status.
And yet the pragmatic task of managing migration requires that the status of a person be known to the state. RSD exists in domestic law to allow a state's immigration bureaucracy to label a particular individual seeking protection as either "legitimate" (refugee) or "illegitimate" (non-refugee) and to thereby grant him or her access to (or refuse access to) various benefits accruing from that status. As the process typically unfolds, a refugee claimant's status is adjudicated based upon information gathered by state agents largely through documentary sources, written statements, and oral statements given during interviews and hearings. In Canada, this function is performed by the Refugee Protection Division (the RPD) of the Immigration and Refugee Board. ${ }^{8}$ The nuance of a non-complaint but nonetheless bona fide refugee is lost in the functionalism of this process.

The legal framework that governs the decision making of the RPD is necessarily a parochial one, that of domestic law. But Canadian law requires that this framework be interpreted, as much as possible (and especially where there is silence), in keeping with Canada's international legal obligations. It is for this reason that the guidance of the latter will be outlined, including international practice, below before proceeding to a more detailed analysis of the domestic legal provisions.

\section{International Legal Framework}

International law, as a principal source of Canada's obligation to offer protection to refugee claimants, provides a framework within which abandonment decisions must be made. While international treaties are not formally a part of Canadian law unless implemented by statute, ${ }^{9}$ the values reflected in international human rights law "may help inform the contextual approach to statutory interpretation and judicial review." ${ }^{10}$ International instruments and practices will be discussed below insofar as they relate to the right to asylum, the right to due process, the norms of refugee determination, and other considerations. While not explicitly addressing the topic of abandonment of refugee claims, international law will be shown to strongly suggest that any decision to abandon should be made with sensitivity to the claimant's situation, with caution and only after full procedural rights have been accorded a claimant. International instruments and customs with respect to refugee determination and other civil proceedings will be shown to require a fair hearing with the claimant being given a reasonable opportunity to retain counsel and an interpreter before any decision with respect to abandonment is made.

The right to asylum ${ }^{11}$ is guaranteed in numerous international declarations, agreements, and treaties. ${ }^{12}$ The most comprehensive assessment of asylum, otherwise known as refugee protection, is provided by the Refugee Convention 
(and the Protocol Relating to the Protection of Refugees ${ }^{13}$ [the Protocol] of 1967). Unfortunately, although not surprisingly, neither of these international agreements deals with the procedures by which a refugee claim should be made or determined. ${ }^{14}$ Consequently, concerning the issue of abandonment both treaties are silent. ${ }^{15}$

Both these international treaties accept that the right to asylum is not without obligation on the claimant. Article 2 of the Refugee Convention requires that a refugee claimant conform to the laws and regulations in the country of asylum (although it provides no explicit consequences for those claimants who fail to so conform). Article 31 predicates relief from prosecution for unlawful entry upon a refugee presenting himself or herself without delay to the authorities and showing good cause for his or her illegal entry. Numerous of the socio-economic rights provided to refugees in the Refugee Convention are provided only to refugees "lawfully" present, staying or residing. ${ }^{16}$ Notwithstanding these provisions, the Refugee Convention's treatment of non-refoulement and expulsion (with respect to bona fide refugees ${ }^{17}$ ) states that only the most serious and criminal breaches of domestic law will allow for expulsion or forced return. ${ }^{18}$

While the Refugee Convention and the Protocol may be silent on the proper procedures by which refugee status is determined (and thus through which claims are abandoned), the UNHCR has issued guidelines. Canadian courts have given weight to the pronouncements of UNHCR, and have, in particular, accepted the importance of the UNHCR Handbook: "[it ]must be treated as a highly relevant authority in considering refugee admission practices." 19 The UNHCR Handbook states (at paragraph 190) that any decisions regarding refugees should be made in the context of their disadvantaged situation:

It should be recalled that an applicant for refugee status is normally in a particularly vulnerable situation. He finds himself in an alien environment and may experience serious difficulties, technical and psychological, in submitting his case to the authorities of a foreign country, often in a language not his own. His application should therefore be examined within the framework of specially established procedures by qualified personnel having the necessary knowledge and experience, and an understanding of an applicant's particular difficulties and needs.

Furthermore, UNHCR has declared in the Handbook that a claimant "should receive the necessary guidance as to the procedure to be followed" and that a refugee determination authority must understand that a claimant may "still feel apprehensive vis-à-vis any authority." ${ }^{20}$ In addition, in commenting on developments in asylum procedures, UNHCR has emphasized that the principle of fairness shall be not superseded by the goal of efficiency. ${ }^{21}$ Thus it would appear that abandonment, like any other determination of a refugee claim, should occur only after a decision maker has ensured that the claimant has received adequate guidance and assistance.

Numerous international human rights treaties provide insight into the striking of a balance between "fairness" and "efficiency" that is necessary in any administrative process. Decisions that affect an individual's legal rights or civil status are generally required by international law to comply with a particular balance of fairness and efficiency: such decisions must meet the standards of due process. For example, Article 14 of the International Covenant on Civil and Political Rights $(I C C P R)$ provides an overarching right to all those facing "a determination of ... his rights and obligations in a suit at law" to "a fair and public hearing by a competent, independent and impartial tribunal established by law." Unfortunately, the minimum standards prescribed by the ICCPR (and also dealt with by Canada in its periodic reports to the treaty monitoring body ${ }^{22}$ ) only explicitly apply to criminal trials. Some jurisprudence suggests that Article 14 of the ICCPR does not apply to immigration proceedings. ${ }^{23}$ However, even if Article 14 does not apply, Article 13 guarantees that expulsion will only occur lawfully "in pursuance of a decision reached in accordance with law" and only after the individual concerned has been allowed "to submit the reasons against his expulsion" to a competent independent authority. ${ }^{24}$ Thus, the ICCPR guarantees a hearing, or at a minimum the right to make submissions on the topic. ${ }^{25}$

While the international treaties may not explicitly define the elements of what constitutes a "fair hearing" in refugee determination in general or abandonment decisions in particular, the ultimate consequence of these decisions suggests that a high standard of due process is required:

\footnotetext{
Most of the countries examined in this paper [comparing refuge determination regimes] do not have the death penalty. Yet for a refugee wrongly rejected and returned to the country from which he has fled, death may be the result. The potential consequences of an error in refugee determination require the highest standards for the determination systems. However, none of the systems comes close to the protection offered to an accused criminal, where the potential harm from error is a good deal less. $^{26}$
}

The analogy of due process guarantees in refugee determination systems and capital trials is apt. ${ }^{27}$ In the context of administering the death penalty case (when consular access rights were violated) the Inter-American Court has held as follows with respect to due process: 
It is obvious that the obligation to observe the right to information becomes all the more imperative here, given the exceptionally grave and irreparable nature of the penalty that one sentenced to death could receive. If the due process of law, with all its rights and guarantees, must be respected regardless of the circumstances, then its observance becomes all the more important when that supreme entitlement that every human rights treaty and declaration recognizes and protects is at stake: human life.

Because execution of the death penalty is irreversible, the strictest and most rigorous enforcement of judicial guarantees is required of the State so that those guarantees are not violated and a human life not arbitrarily taken as a result. ${ }^{28}$

This logic applies equally to the nature of an abandonment decision and its consequences which, after the removal of the claimant, is effectively irreversible and which is potentially the cause of inestimable harm to a bona fide refugee. Pursuing this logic, the Federal Court frequently has considered the potentially dire consequences of abandonment in assessing the fairness of the decision. ${ }^{29}$ Thus, in addition to requiring a hearing, international law requires that any abandonment process provide the claimant with procedural rights-and that these rights be rigorously enforced.

\section{Particular Refugee Determination Guidelines}

While there is no universally accepted system of refugee determination, procedural rights afforded refuge claimants in other refugee determination systems may provide guidance about generally accepted notions of procedural rights in the context of refugee determination. As noted in the Federal Court of Appeal's decision in Rahaman, ${ }^{30}$ Canadian courts should look to accepted international norms when interpreting aspects of the Refugee Convention which are undefined. ${ }^{31}$

As noted earlier, the UNHCR, through its Handbook, has provided some general guidance on general refugee determination procedures. In addition, the Executive Committee (ExCom) of UNHCR has adopted a resolution ${ }^{32}$ requiring a refugee determination process to include, among other elements, (i) the provision of guidance to the refugee claimant as to the procedure to be followed, (ii) the provision of the necessary facilities, including the services of a competent interpreter, for submitting his case to the authorities concerned, and (iii) the opportunity for a refugee claimant, of which they should be duly informed, to contact a representative of UNHCR. UNHCR's own refugee status guidelines for its own decision makers require it not to abandon (close) a refugee claim unless the decision maker loses contact with a claimant for more than six weeks following the scheduling of an interview. ${ }^{33}$ Even where cases are "closed," requests for a "re-opening" of the claim should "generally be granted." 34

The Council of Europe has adopted a general framework of substantive and procedural rights which give substance to the prescription against the refoulement of refugees. The Council's Resolution on Minimum Guarantees for Asylum Procedures ${ }^{35}$ states, in part, as follows:

1. 13. Asylum-seekers must be informed of the procedure to be followed and of their rights and obligations during the procedure, in a language which they can understand. In particular:

2. - they must be given the services of an interpreter, whenever necessary, for submitting their case to the authorities concerned. These services must be paid for out of public funds, if the interpreter is called upon by the competent authorities,

3. - in accordance with the rules of the Member State concerned, they may call in a legal adviser or other counselor to assist them during the procedure,

4. $\quad \ldots$

5. 14. Before a final decision is taken on the asylum application, the asylum-seeker must be given the opportunity of a personal interview with an official qualified under national law.

The European Union's binding minimum procedural standards also require a hearing in most cases. ${ }^{36}$ Exceptions to this provision are permitted only where the decision is positive, ${ }^{37}$ where there has been a prior interview of some kind, ${ }^{38}$ or where evidence already provided by the refugee claimant indicates that the claim is manifestly unfounded. ${ }^{39}$ Even where a decision is made to abandon a refugee claim due to the failure of a refugee to attend an interview, the $E U$ Procedural Directive allows for the right of reopening where good cause for non-attendance is shown. ${ }^{40}$

Thus the right to a hearing is not only required by international law, but also customarily accorded in other refugee determination systems. Furthermore, applying both the UNHCR and European frameworks, an abandonment decision should not be made before a claimant has been accorded a reasonable opportunity to retain legal counsel and the services of an interpreter (if required). The right to counsel and an interpreter is a right that predates a hearing and it is a right that persists throughout the determination procedure. Where a claim is abandoned, a refugee claimant should have the ability to reopen his or her claim upon establishing good cause for the abandonment. As will be seen below, Canadian law frequently fails to provide these procedural protections.

\section{Other International Law Considerations}

As noted at the outset of this discussion on international law and practice, there is little explicit guidance in international 
law with respect to abandonment decisions; not all countries even have such procedures. However, there is much broader international jurisprudence on "manifestly unfounded" claims. While in Canada, the statutory framework separates abandonment determination from the determination of whether a claim is manifestly unfounded, in practice the result is identical: an expedited removal process with no access to subsequent risk assessments. ${ }^{41}$ In some limited sense, an abandonment decision can be seen as a "manifestly unfounded" decision in a different guise. ${ }^{42}$ It is therefore instructive that even "fraudulent applications" (which form a subset of UNHCR's definition of manifestly unfounded refugee claims) should be accorded procedural protections, including the right to an oral hearing. ${ }^{43}$ This suggests that determinations of abandonment, which are made without alleging fraud, should accord the claimants similar procedural protections.

\section{Domestic Legislative Framework}

The jurisprudence on abandonment has built up over a significant period of time. As a result, both the current and previous legislative frameworks must be reviewed. The Immigration $\mathrm{Act}^{44}$ was the governing statute for refugee protection in Canada from 1978 to 28 June 2002. ${ }^{45}$ The Convention Refugee Determination Division (CRDD) of the Immigration and Refugee Board had jurisdiction over the determination of refugee claims in Canada-and consequently the abandonment of refugee claims-between its establishment in $1993^{46}$ and 27 June 2002. Since 28 June 2002, under the Immigration and Refugee Protection Act ${ }^{47}$ (IRPA), the Refugee Protection Division of the Board has had jurisdiction over refugee claims and their abandonment.

The decision by the Board, under both the Immigration Act and the IRPA, to declare a refugee claim to be abandoned is a final decision. A valid abandonment decision causes the Board to become functus officio over the refugee claim as it represents the final disposition of the claim. Under both the Immigration Act and the IRPA, a declaration of abandonment by the Board has severe consequences for a claimant. A conditional removal order (which is typically issued shortly after a claimant makes a refugee claim) becomes effective upon the abandonment of the claim by the Board and the notification thereof of the claimant. ${ }^{48}$ Under the IRPA, an abandonment decision can have the further effect of barring the claimant from being eligible to seek refugee or other protection in Canada in the future. ${ }^{49}$

\section{Immigration Act provisions relating to abandonment}

Under s. 69.1(6) of the Immigration Act the CRDD had the discretionary power to declare a refugee claim to be aban- doned. The two condition precedents to the exercise of this power were (i) the default of the claimant in the prosecution of the refugee claim, and (ii) the provision to the claimant of a "reasonable opportunity to be heard" on issue of abandonment. ${ }^{50}$

The Immigration Act defined the first condition precedent to abandonment as any of the following: the failure to appear for a hearing, ${ }^{51}$ the failure to file a completed Personal Information Form (PIF), 52 and "in the opinion of the Division" being "otherwise in default in the prosecution of the claim." 53

As a matter of practice, the CRDD considered the failure to provide a PIF within the prescribed time period (from 28 to 42 days depending on the methods of service and filing ${ }^{54}$ ) as being "otherwise in default in the prosecution of the claim." In her practice notice ${ }^{55}$ on the subject, the Chairperson of the Board advised counsel that "[i]f a PIF is not filed within the prescribed time, a notice to appear for a show cause hearing will be issued." 56

The second condition precedent for the abandonment of a refugee claim under the Immigration Act was the provision to the claimant of a "reasonable opportunity to be heard." 57 While a "reasonable opportunity" was not defined in the Immigration Act, Rule 32 of the CRDD Rules provided some guidance on the matter. Rule 32(1) required service of a notice of an abandonment hearing. Thus, at a very minimum the Board was required to hold a hearing on the subject and to notify the claimant of this hearing. ${ }^{58}$

The Immigration Act did not explicitly state the circumstances under which the CRDD should abandon a refugee claim. The power to abandon was a discretionary power. However, the Immigration Act did provide guidance to the CRDD concerning the general principles of its operation. Section 68(2) of the Immigration Act requires the CRDD to "deal with all proceedings before it as informally and expeditiously as the circumstances and the considerations of fairness permit."

Echoing this mandate, the CRDD Rules allowed the CRDD to "take whatever measures are necessary ... to dispose of the matter expeditiously" 59 and to allow a party to remedy non-compliance only where "the proceeding will not be unreasonably impeded." 60 However, neither of these provisions allowed the CRDD to waive a hearing concerning an abandonment decision before declaring a claim to be abandoned.

\section{Immigration and Refugee Protection Act provisions relating to abandonment}

While the Immigration Act provided a framework for abandonment particular to refugee claimants, the IRPA provides a general framework for abandonment governing all divisions 
of the Board, including the RPD. ${ }^{61}$ Once again, the power to abandon is discretionary.

Section 168(1) of the IRPA allows any division of the Board to abandon a matter "if the Division is of the opinion that the applicant is in default in the proceedings." While the IRPA in its statutory provisions for abandonment does not, unlike the Immigration Act, explicitly require that a refugee claimant be provided with a reasonable opportunity to be heard concerning the abandonment, other provisions of the IRPA and the Refugee Protection Division Rules (the RPD Rules) do set out such a requirement in most cases.

Being in "default in the proceedings" is defined by s. 168(1) of the IRPA as including situations where (i) a claimant fails to appear for a hearing, (ii) a claimant fails to provide information required by the RPD, or (iii) a claimant fails to communicate with the RPD after being requested to do so.

With respect to the failure to provide required information, the RPD Rules distinguish "information" from "documents." 62 Thus the failure to provide required information may lead to abandonment but the failure to provide required documents may only lead to abandonment if it leads to the RPD making the further conclusion that the claimant is "in default of the proceedings." Required information includes (i) the claimant's contact information, ${ }^{63}$ and (ii) counsel's contact information. ${ }^{64}$ Arguably, as the PIF is described as a document in the RPD Rules ${ }^{65}$ (as opposed to as a set of information in the CRDD Rules ${ }^{66}$ ), failure to file a PIF simpliciter cannot provoke an abandonment decision; there must be a concomitant finding of "default in the proceedings."

With respect to failure to communicate with the RPD, the $R P D$ Rules (as noted above) do require certain notifications of information to be provided by the claimant to the RPD. However, the term "request" in s. 168(1) suggests a claimantspecific non-universal communication ${ }^{67}$ which would preclude universally required notifications. Furthermore, as the failure is defined as one of "communication," it would appear that the deficiency concerns the act (or failure thereof), and not the content, of communication.

Although specified in the definition of being in "default of the proceedings," these three instances do not provide an exhaustive definition of being in default. In addition to these instances, the Commentaries on the RPD Rules warns that where a claimant "is not prepared to proceed, the Division may determine that the proceeding before it has been abandoned." Thus being unprepared (or more likely unwilling) to proceed would also be considered as being explicitly in default of the proceedings. As with the Immigration Act, the lists of defaults that may lead to abandonment set out in the IRPA should not be seen as exhaustive. Clearly, the RPD retains the ability to find other circumstances as being indicative of default.
The abandonment provisions of the IRPA do not explicitly provide for a reasonable opportunity to be heard prior to abandonment. However, s. 170(b) of the IRPA does require the RPD to hold a hearing in "any matter before it." Consequently, it can be inferred that even a matter destined for abandonment is guaranteed a hearing on the subject. However, as obvious as this might seem, a problematic exception to this rule is set out in the RPD Rules. This exception is discussed further below.

However, dealing first with the rule in general before considering the exception, s. 170 of the IRPA requires (i) that the RPD must hold a hearing "in any proceeding before it"; (ii) must notify the claimant of the hearing; and, (iii) must give the claimant "a reasonable opportunity to present evidence, question witnesses and make representations" at the hearing. ${ }^{68}$ In addition, the RPD Rules require that, with the exception noted below, the claimant be provided with an "opportunity to explain why the claim should not be declared abandoned." 69 Unlike the CRDD Rules, the RPD Rules do not require prior written notification of the claimant where the claimant is present and it would be fair to proceed without written notice. ${ }^{70}$

The exception to the requirement in the RPD Rules to give a claimant a reasonable opportunity to be heard is where the claimant has failed to advise the Board, the Minister, or counsel of his or her whereabouts. ${ }^{71}$ In such a case, under Rule 58(1), the RPD is not required to hold an abandonment hearing. Indeed, according to this rule, the RPD is not required to give the claimant any opportunity to explain why the claim should not be declared abandoned.

Although it is beyond the scope of this paper to exhaustively examine the subject, it would appear that Rule 58(1) of the RPD Rules is void insofar as it is ultra vires the rule-making powers conferred upon the Chairperson of the Board. This analysis is based upon the following factors: (i) Rule 58(1) improperly qualifies a statutory right; (ii) the statutory right in question is not ambiguous; (iii) any other interpretation would infringe unduly upon the rights of refugee claimants; and (iv) any other interpretation would infringe on the construction of the statute required by its domestic and international legal context. The impact of each of these factors upon the conclusion that Rule $58(1)$ is ultra vires is discussed in sequence below.

Firstly, Rule 58(1) is ultra vires insofar as it improperly qualifies a statutory right. The rule in question clearly infringes upon s. 170(b) which requires a mandatory hearing in all refugee proceedings. In addition, the rule also infringes upon subsections 170 (c) and (e) which require notice of a hearing and the right to make representations (at a hearing or otherwise).

The RPD Rules are made under the power of s. 161 of the $I R P A$. In subject matter, the rule in question falls within the 
scope of s. 161(1)(b) (and also s. 161(1)(d) ${ }^{72}$ ). However, as a delegated instrument, it cannot exceed the authority of its parent statute. ${ }^{73}$ In this case the statute clearly lays out a scheme of mandatory hearings in all refugee matters. Furthermore, unlike other statutory schemes, there is no explicit power conferred to the Chairperson to make rules allowing for exceptions to the statutory scheme. ${ }^{74}$ As stated by Dussault and Borgeat, a regulation exceeds the authority of its authorizing statute insofar as it authorizes "administrative discrimination":

However, the criteria for discrimination [of human rights legislation] set out in these provisions are not the only ones that are subject to judicial supervision insofar as the exercise of a regulation-making power is concerned. Indeed, the courts often consider that Parliament alone must possess this delicate power which consists in disadvantaging one category of citizens in relation to another. ${ }^{75}$

Unauthorized discriminatory regulatory provisions-in the neutral sense of "discriminatory" used above-have been struck down by the courts. ${ }^{76}$ The rule in question exceeds the authority delegated to the Chairperson insofar as it is discriminatory; moreover the discrimination in question improperly qualifies the rights guaranteed in the statutory scheme. As a result, the rule in question is quite likely ultra vires.

Secondly, there is no ambiguity in the IRPA surrounding Parliament's desire to guarantee a hearing to all refugee claimants. If anything, the French-language version of s. 170(b) is even stronger than the English-language version. ${ }^{77}$ The significance of s. 170 (b) is reinforced both by the absence of a similar provision guaranteeing hearings in relation to the other divisions of the Board ${ }^{78}$ and also by the absence of a similarly clear and unambiguous provision guaranteeing a hearing in the Immigration Act. ${ }^{79} \mathrm{~A}$ similar provision guaranteeing hearings was also included in the Government's previously proposed legislation on refugee claims that died on the order paper with the end of the $36^{\text {th }}$ session of Parliament. ${ }^{80}$ Even the regulatory statement accompanying the prepublication of the RPD Rules provides no justification or explanation of Rule 58(1). ${ }^{81}$ The lack of ambiguity in the statutory scheme requiring hearings in matters before the RPD undermines any broad interpretation of the Chairperson's power to make rules making exceptions from the provisions of the statute.

Thirdly, to construe the IRPA otherwise would be to unduly encroach upon the right of a refugee claimant to a hearing. As stated in Maxwell on the Interpretation of Statutes (12th ed., 1969, at pages 251-52) and quoted with approval in Leiriao v. Val-Bélair (Town) ${ }^{82}$ :
Statutes which encroach on the rights of the subject, whether as regards person or property, are subject to a strict construction in the same way as penal Acts. It is a recognized rule that they should be interpreted, if possible, so as to respect such rights, and if there is any ambiguity the construction which is in favour of the freedom of the individual should be adopted.

This approach has been previously applied by the Supreme Court of Canada to refugee determination. ${ }^{83}$ Thus any possible (unseen) ambiguity in the statute and regulations should be interpreted to protect a claimant from being deprived of his or her right to a hearing.

Fourthly, any interpretation should also be in keeping with the domestic and international framework of refugee protection. Section 3(2) specifically deals with the objectives of the IRPA in relation to refugee protection. These objectives include the following: (i) "to fulfil Canada's international legal obligations with respect to refugees", (ii) "to grant ... fair consideration to those who come to Canada claiming persecution", and (iii) "to establish fair and efficient procedures that will maintain the integrity of the Canadian refugee protection system." 84 None of these purposes, except with a very oblique reading, is contemplative of establishing special procedures to deal with uncooperative refugee claimants. While the objectives do speak of "expediency" as an objective, the jurisprudence is clear that fairness has priority over expediency as a goal when assessing the exercise of discretionary power; a similar priority should apply to the interpretation of statutory objectives.

Furthermore, there is a broader domestic legal context within which to consider the provisions of the IRPA and the RPD Rules. Section 7 of the Canadian Charter of Rights and Freedoms is relevant insofar as it requires that certain actions are in accordance with the principles of fundamental justice; the right to a fair hearing provision of s. 2(e) of the Canadian Bill of Rights ${ }^{85}$ also provides for the right to a fair hearing in accordance with those same principles of fundamental justice.

With respect to the Charter, the jurisprudence indicates that inland refugee determination engages s. 7 of the Charter and therefore must be in keeping with the "principles of fundamental justice." ${ }^{86}$ Baker $^{87}$ (and later Suresh ${ }^{88}$ ) set out a context driven approach to the determination of procedural safeguards. Following this approach, the important and final nature of a decision to abandon a refugee claim as well as the clearly judicial nature of the RPD's activities suggest a high level of procedural protection, including the right to an oral hearing or the right to make representations. While the jurisprudence has recently allowed for less than an oral hearing, notably in both Baker and Suresh (above), the processes in question in those cases were not directly related to 
refugee determination, administratively structured, discretionary, and based upon policy considerations. The refugee determination process does not possess any of these features, which may mitigate in favour of less than the right to a full oral hearing.

With respect to the Canadian Bill of Rights, although of less import since the adoption of the Charter, the jurisprudence indicates that s. 2(e) guarantees the following minimum standard of conduct by a quasi-judicial body:

Under s. 2(e) of the Bill of Rights no law of Canada shall be construed or applied so as to deprive him of "a fair hearing in accordance with the principles of fundamental justice". Without attempting to formulate any final definition of those words, I would take them to mean, generally, that the tribunal which adjudicates upon his rights must act fairly, in good faith, without bias and in a judicial temper, and must give to him the opportunity adequately to state his case. ${ }^{89}$

The international legal context of Canada's refugee determination system is, as acknowledged in the stated purposes of the IRPA quoted above, that the IRPA seeks to implement the obligations towards refugees recognized under international law. As noted in both Baker and Suresh (above) and as stated previously by the Supreme Court of Canada in National Corn Growers Assn. v. Canada (Import Tribunal) ${ }^{90}$ :

... [I]n circumstances where the domestic legislation is unclear it is reasonable to examine any underlying international agreement. In interpreting legislation which has been enacted with a view towards implementing international obligations, as is the case here, it is reasonable for a tribunal to examine the domestic law in the context of the relevant agreement to clarify any uncertainty. Indeed where the text of the domestic law lends itself to it, one should also strive to expound an interpretation which is consonant with the relevant international obligations.

As noted at the outset of this paper, in the discussion of the international legal framework of refugee determination, there is both a general acceptance of the right to due process, including an oral hearing, in refugee determination and a practical accordance of an oral hearing to refugee claimants.

In closing, concern about Rule 58(1) is not purely of theoretical concern. Indeed, it is possible to conceive of a situation (for example, involving a claimant with mental illness or a claimant who has simply traveled to a remote location for work) where counsel (and the Minister and the Board) may not know the contact information of the claimant but counsel may have information or witnesses relevant to the issue of abandonment. In such a case, Rule 58(1) would allow the Board to dispense with a hearing notwithstanding its clear utility. It is also clear that there are groups of refugee claimants, such as unaccompanied minors, who should seldom (if ever) be abandoned without some inquiry as to their circumstances.

Provisions such as Rule 58(1) erode the rights of refugee claimants. In the past, the jurisprudence has allowed the Board to assume a claimant had "implicitly waived" some rights in relation to abandonment proceedings; however such waivers have always been restricted to rights accorded by the Board's rules and never statutory rights. ${ }^{91}$ It would be an ominous expansion of the scope of the Board's power to allow it to deem statutory rights "implicitly waived" and thereby bypass statutory guarantees of a hearing.

The IRPA, like the Immigration Act, mandates that proceedings be dealt with as expeditiously as possible. ${ }^{92}$ However, unlike the CRDD Rules, the RPD Rules provide some guidance concerning what information to consider when deciding whether to abandon a claim. The RPD must consider (i) the explanations given by the claimant at the hearing, (ii) whether the claimant is ready to start or continue the proceedings, and (iii) any other relevant information. ${ }^{93}$ These considerations are technically subject to waiver under Rule 69 of the RPD Rules - although it is difficult to imagine such a waiver.

\section{Remedies to abandonment decision}

There are two courses of action available to a claimant seeking to challenge the decision by the Board to abandon his or her refugee claim. A claimant may (i) apply for leave for judicial review with the Federal Court, and/or (ii) request by way of motion ${ }^{94}$ that the Board reopen its decision to declare the claim to be abandoned. These remedies are independent of each other and may be pursued in sequence or in tandem. In both cases, given that an abandonment hearing involves findings of both fact and law, if the reviewing body finds an error it should almost always grant relief. ${ }^{95}$ The result of both a successful judicial review (of an abandonment decision) and a successful motion to reopen should be the quashing of the declaration of abandonment and remittance either (i) to a new panel of the Board for a rehearing of the issue of abandonment, or (ii) to a new panel of the Board for a determination of the claimant's refugee claim. ${ }^{96}$

The Immigration Act and the IRPA allow for judicial review with the leave of the Federal Court of abandonment decisions. An application for leave for judicial review must generally be initiated within fifteen days of receipt by a claimant of the abandonment decision. ${ }^{97}$ The judicial review must be contemporaneous with the abandonment decision - and not any later conclusion of proceedings (with the exception of motions to reopen, discussed below). ${ }^{98}$ With the exception (discussed below) of extending the time limit for the filing of 
the application, the Court will require strict adherence to the rules of court for claimants seeking to set aside abandonment decisions. ${ }^{99}$ The standard of review is correctness concerning issues of natural justice and procedural fairness and reasonableness simpliciter for all other issues. ${ }^{100}$

Unusually, the Court has shown a willingness to consider new evidence at the judicial review where the new evidence provides an exculpatory explanation for the alleged default in prosecution which resulted in abandonment and the new evidence was not previously available. ${ }^{101}$ Furthermore, the Court has also drawn negative inferences where such new evidence would be reasonably expected to be presented upon judicial review. ${ }^{102}$

Obviously, the rejection of a motion to reopen can also be the subject of judicial review. ${ }^{103}$

A limited body of jurisprudence indicates a willingness of the Federal Court to grant an extension of the deadline for filing for judicial review where the delay is directly a result of seeking redress through a motion to reopen before seeking judicial review of the underlying abandonment decision. ${ }^{104}$ However, sequential judicial reviews of both an abandonment decision and then a denial of a motion to reopen may be barred by the doctrine of res judicata. ${ }^{105}$

An alternative remedy is to apply by way of motion to the Board to set aside the abandonment decision and to reopen the claim. As at common law, only a valid abandonment decision causes the Board to become functus officio, such a motion must challenge the validity of the Board's decision. To do so, the motion should present evidence that was not previously before the Board indicating that the claimant was denied natural justice. ${ }^{106}$ Rule 55 of the RPD Rules codifies this common-law rule by explicitly providing for a motion to re-open based upon the "failure to observe a principle of natural justice." 107

A motion to reopen must be filed as quickly as possible with the Board. Any delay between the abandonment decision and the filing of a motion to reopen necessitates a clear and complete explanation. ${ }^{108}$ In addition, any default that can be remedied (for example, the failure to file a PIF) should be remedied as soon as possible and no later than the filing of the motion. ${ }^{109}$

The Board and the Courts have established that motions to reopen will be granted where they show the abandonment decision to have been contrary to the principles of natural justice. ${ }^{110}$ As the requirements of natural justice primarily relate to the right to receive a fair hearing, a motion will be most likely to succeed when it challenges an abandonment decision made in the absence of the claimant.

According to the CRDD Rules, the RPD Rules, and principles of natural justice, the Minister must be given an opportunity to respond to any motion. ${ }^{111}$ Although not explicitly stated in the jurisprudence or the relevant rules, the standard of review is proof on a balance of probabilities. ${ }^{112}$ The principle of res judicata applies to motions to reopen; therefore, a claimant will generally only be entitled to consideration of one such motion. ${ }^{113}$

The most significant disadvantage of a motion to reopen is that not only does it not bar removal pending the Board's determination of the motion but also the courts have been hesitant to stay execution of a removal order where a motion to reopen is pending. ${ }^{114}$ However, the Board has exercised its jurisdiction to decide a motion where a claimant is outside of Canada ${ }^{115}$ and where a claimant has been deported and subsequently returned to Canada. ${ }^{116}$ Although the current practice of the Board is not to provide formal written reasons explaining its determinations of motions to reopen, the Registrar of the Board does provide, upon request, a transcript of the (usually brief) "endorsement" that appears on the file justifying the decision. ${ }^{117}$

\section{Jurisprudence}

For a variety of reasons, not least of which is the fact that the IRPA has been in effect for a shorter period of time than the Immigration Act, most of the jurisprudence concerning the abandonment of refugee claims has been decided under the Immigration Act. ${ }^{118}$ As noted earlier, abandonment decisions can be remedied through an application to the Board or through judicial review in the Federal Court. Although technically possible if a case before the Federal Court is certified to concern a matter of "general importance,"119 there have been few decisions of the Federal Court of Appeal dealing directly with abandonment.

Although both the Immigration Act and the IRPA are structured so as to allow the Board to expand the possible grounds for abandonment, in fact the jurisprudence appears to limit the grounds. The jurisprudence does not often stray beyond the defaults in prosecution explicitly defined in the statutes and limits even those defaults, as discussed below, by adding a required mental component. However, the jurisprudence has relatively generously construed a claimant's reasonable opportunity to be heard on the subject of abandonment. The decisions of the Board and the Federal Court will be discussed below insofar as they relate to both these elements of the abandonment scheme. Both the jurisprudence's interpretation of the legislative framework's definitions of "default in prosecution" and its understanding of the requirement that a claimant have a "reasonable opportunity to be heard" will be discussed in sequence below.

\section{Default in Prosecution}

A default in prosecution of a refugee claim provokes an abandonment hearing. The statutorily defined (under both the 
Immigration Act and the IRPA) defaults (which are also the most common in the jurisprudence) are (i) failing to submit a PIF within the deadline, and (ii) failing to appear for a hearing. A third common default is a claimant's deliberate refusal to proceed with the hearing of his or her claim by the Board.

As discussed below, in order to be sufficient for abandonment any default must include not only the act constituting default but also an accompanying mental intention. ${ }^{120}$ The level of mental intention required includes not only wilful acts but also acts of wilful blindness. It is the lack of required mental intention which is the most common "defense" offered at an abandonment hearing. Obviously, any such defense only prevents abandonment if it is believed by the Board. ${ }^{121}$ The claimant bears the burden of proof. The third ground of default cited above (the refusal to proceed with the hearing of his or her claim) does not allow a claimant to bring into question whether the act is deliberate.

In assessing any default of prosecution of his or her refugee claim, the Board must consider the matter holistically. ${ }^{122}$ The history of the file, including delays and breaches of the rules attributable to the claimant, are appropriate matters for consideration by the Board. ${ }^{123}$ The Board has also considered the claimant's actions before the referral of the claim to the Board. ${ }^{124}$ As stated by Nadon, J. (albeit in obiter dicta) in Kavunzu v. M.C.I.125:

It seems to me that the "default" has to be interpreted having regard to all the circumstances of the case, i.e., the date of the claimant's arrival, whether or not a personal information form was filed, whether or not counsel was retained in a timely manner, one or more previous absences when directed to appear, etc. Therefore, in my view, when a claimant fails to comply with an appearance date, the Refugee Division should have regard to all of the circumstances I have mentioned in deciding whether the claimant in the case before it "is otherwise in default in the prosecution of the claim."

Unfortunately, the Board does not need to consider these matters within the context of its own (relatively) slow process. ${ }^{126}$ Also, the jurisprudence is at the very least silent, and likely opposed, to the consideration of the relative merits of the refugee claim in the holistic determination of whether there has been a default. ${ }^{127}$ On this point, a clearly wellfounded claim would seem to suggest that a (reasonable) claimant would not deliberately default in its prosecutionthereby circumstantially corroborating the claimant's proffered explanation. However, the Board does not explicitly consider this in the jurisprudence as a corroborative factor in assessing the claimant's explanation for default-although many of the Court's and the Board's decisions do seem to imply the converse.
While the Board can consider the matter holistically, the focus of abandonment proceedings is in the past actions (or inactions) of the claimant. A subsequent demonstrated willingness to prosecute the claim (for example, on the occasion of the abandonment hearing) does not prevent the Board from declaring the claim to be abandoned. ${ }^{128}$ However, notwithstanding that it does not prevent an abandonment decision, the Board must at least accurately consider the willingness of a claimant to proceed with his or her claim at the abandonment hearing. ${ }^{129}$

Perhaps the most common default that leads to abandonment proceedings is the failure by a claimant to file a completed PIF with the Board within the prescribed time period. As the PIF provides the Board with the claimant's core biographical data and material allegations of risk, the default in the timely filing of the PIF is considered to be a serious default; extensions to the deadline for the filing of the PIF are only granted according to Board policy on an "exceptional" basis. In order to remedy a default in filing a PIF, the Board may grant an adjournment of the abandonment hearing to allow the claimant to file a PIF before the resumption of proceedings. ${ }^{130}$ However, obviously a better practice is to ensure the PIF is filed well before the abandonment hearing-although this will not automatically vitiate the need for a hearing.

There are two commonly cited reasons for the failure to file a PIF within the required time period: (i) the failure to receive the PIF, and (ii) difficulties in answering the questions contained within the PIF. These reasons will be discussed in sequence below.

Firstly, a claimant's failure to file a PIF may be explained by his or her failure to receive a PIF. ${ }^{131}$ Notwithstanding the Ministry's notice to the Board that it has served the claimant with the PIF, it may not have been received by the claimant or it may have been received late. ${ }^{132}$ Although the CRDD Rules and RPD Rules allow for deemed service, the failure to receive a PIF provides an exculpatory explanation for failing to file the PIF within the prescribed time period. If a claimant provides uncontradicted evidence that he or she has not received a PIF, there is no reason to declare the claim abandoned. ${ }^{133}$ In such a case, the default in question is not deliberate.

Secondly, a PIF may not have been filed in a timely manner because of difficulties in completing the PIF. However, any explanation offered by a claimant for delay in filing the PIF must carefully account for the complete period of the delay. ${ }^{134}$ Difficulty in meeting with counsel or an interpreter, in the absence of evidence of no other alternative, is not a sufficient reason for delay (or at least a lengthy delay) in the filing of the PIF. ${ }^{135}$ The lack of receipt of disclosure from the Board or the Ministry is not an acceptable "difficulty" in failing to complete the PIF. ${ }^{136}$ 
In keeping with its practice notice on the subject, ${ }^{137}$ the Board must consider any pending (perhaps post facto) requests for an extension of the PIF deadline before declaring a claim to be abandoned. ${ }^{138}$ Obviously, the default (of failing to file before the deadline) is remedied if an extension is granted. The mere denial of a request to extend the PIF deadline (and a consequent failure to file the PIF by the deadline) cannot automatically result in the abandonment of the claim as the grounds for determining extension requests and for making abandonment decisions are different. ${ }^{139}$

In relation to difficulties in completing the PIF attributable to counsel, care must be taken to distinguish errors of counsel that result in a default from errors of counsel that deny a claimant a reasonable opportunity to be heard on the subject of abandonment. While, as discussed below, the latter have been found to vitiate an abandonment decision, the Board and the Courts have shown a less forgiving attitude to the former, often abandoning claims where delays or failures were due to the delays or negligence of counsel. ${ }^{140}$

Failing to attend a hearing as required by the Board can result also in the abandonment of a refugee claim. This is sometimes combined with the failure to file a PIF-as when a claimant commits the former, is ordered to appear for an abandonment hearing and then fails to attend the hearing. As noted above, in order for an abandonment to occur there must exist both the act of failing to attend the hearing and the intention of not pursuing the claim. ${ }^{141}$ There may be an exculpatory reason for failing to attend a hearing. Once the Board has determined that the claimant has been notified of the hearing in accordance with its procedures, the Board is entitled to presume from the claimant's failure to attend that he or she is deliberately in default of prosecution of his or her refugee claim. ${ }^{142}$ However, where the claimant does attend for at least some of the hearing, this presumption is arguably rebutted. ${ }^{143}$

The commonly cited explanations for a claimant's failure to appear include: (i) lack of knowledge of the hearing date; (ii) physical inability to attend; (iii) misunderstanding as to the hearing date; (iv) illness; and (v) unwillingness to proceed. These reasons will be discussed in sequence below.

Firstly, the lack of awareness of a hearing dates provides a complete explanation for failing to appear. This explanation is to failing to attend a hearing what alleging a failure to receive the PIF is to failing to file a PIF. However, unlike service of the PIF, the Board is normally responsible for service of notice of hearing dates. The records of the Board will therefore normally establish that the Board notified the claimant, at the very least, by post of the hearing date. ${ }^{144}$ To rebut this presumption of notice the claimant must provide credible evidence that he or she did not receive notice of the hearing through no fault of his or her own ${ }^{145}$ and establish that he or she was otherwise diligently prosecuting the claim. ${ }^{146}$ As a matter of credibility, where a claimant admits residing at the address of service and there is no evidence of the notice not having been delivered, it will be difficult for the Board to accept the claimant's evidence that he or she did not receive notice of the hearing. ${ }^{147}$

Obviously, if the claimant is in fact informed of the hearing date by some other means an error by the Board in notifying the claimant is irrelevant. ${ }^{148}$ Failing to receive a notice as a result of knowingly failing to advise the Board of his or her address is equally not an adequate excuse; a claimant who places himself in a position where communication is difficult or non-existent cannot plead lack of knowledge of what was occurring for excusing delay or a failure to appear. ${ }^{149}$

Finally, a claimant may in some circumstances successfully rely upon the negligence of counsel to explain his or her alleged lack of knowledge of a hearing date. The impact of such negligence in abandonment decisions is discussed below under the topic of what constitutes a reasonable opportunity to be heard.

One possible reason for failing to attend a refugee hearing is a claimant's misunderstanding of or forgetfulness of the date of the hearing. However, a bald assertion of a misunderstanding about a hearing date or the requirement to attend is unlikely-absent a cogent explanation-to be accepted. ${ }^{150}$ Language difficulties (and the lack of competent interpretation) can sometimes result in a genuine misunderstanding. ${ }^{151}$ When such an explanation is proffered, the Board can reasonably seek corroboration of the account through, for example, his or her account of contact with counsel. ${ }^{152}$

The impossibility of the claimant attending the office of the Board may provide an acceptable explanation for the claimant's absence; ${ }^{153}$ mere difficulty or "logistical problems" in attending will not generally provide an acceptable explanation. ${ }^{154}$ However, in the face of repeated denials of a claimant's request for a change of venue, a claimant's continued failure to attend (despite practical impossibility) may well result in abandonment. ${ }^{155}$ Furthermore, while being in custody may provide an excuse for a claimant's absence, failure to advise the Board of this fact (thereby preventing the Board from addressing this issue) may provide an independent reason for abandonment. ${ }^{156}$ Ultimately, in both the situation of a claimant in custody and the situation of a claimant quite distant from the Board's office the rules of the Board (allowing for release from custody to attend a hearing and attendance at a hearing by teleconference) will prevent either explanation from being accepted indefinitely.

Although similar to being physically unable to attend, medical illness is different insofar as it is a phenomenon which the Board has no real ability to remedy. Medical illness is obviously a valid explanation for failing to attend a 
hearing. As an event outside of the control of the claimant (or, where it is the illness of counsel, outside of the control of counsel), failure to appear as a result of infirmity should not result in the abandonment of a refugee claim-although it is likely to provoke an abandonment hearing. In the case of such illness, the Board expects the claimant to present "clear, detailed and unequivocal documentation" 157 of the illness. ${ }^{158}$ Any qualified medical personnel providing such documentation should be aware of its use as an explanation for the claimant's absence. ${ }^{159}$

At an abandonment hearing resulting from the claimant's illness, if the Board does not impeach the claimant's (or counsel's) evidence of illness the Board cannot declare the claim to be abandoned. ${ }^{160}$ Furthermore, lacking any medical expertise, the Board should not substitute its own opinion concerning the claimant's medical condition for that of a qualified medical practitioner treating the claimant. ${ }^{161}$ However, the lack of medical evidence does leave it open to the Board to disbelieve that the claimant was ill. ${ }^{162}$ Any medical evidence must not only establish illness, but also that the illness was serious enough to prevent the claimant from attending the hearing. ${ }^{163}$

On occasion, a claimant does attend his or her hearing but advises the Board that he or she is unable or unwilling to proceed with the hearing. Although such an action may lead to the claimant removing himself or herself from the hearing room (and thereby being in breach of the requirement to attend), the Board's determination of abandonment usually correctly focuses on the underlying intention of the claimant not to proceed. The Board may treat such an action as evidence of a default in the prosecution of the claim.

The most common explanation for such action is the lack of availability of counsel. While claimants have the right to counsel, this right is not absolute. ${ }^{164}$ Where a claimant refuses to proceed with qualified counsel, delays in retaining counsel, or retains unavailable counsel the Board may find that the claimant has defaulted in the prosecution of the claim. ${ }^{165}$ This is especially likely when a claimant retains new counsel at the last minute who is unable or unwilling to proceed. ${ }^{166}$ With respect to delay, a delay as short as three weeks in retaining new counsel (when previous counsel was unavailable on the hearing date) has been found by the Board to indicate a lack of diligence in the prosecution of the claim. ${ }^{167}$

\section{Reasonable Oppoortunity to Be Heard}

The Board is generally required to hold a hearing on the subject of abandonment before declaring a claim to be abandoned. As always, the Board must advise the claimant of the hearing and must allow the claimant a reasonable opportunity to address the issue at the hearing. ${ }^{168}$ The failure to provide a reasonable opportunity to be heard does not require a finding of deliberate fault; it can occur without the knowledge of Board (for example, due to postal or interpretation error). ${ }^{169}$ Furthermore, although in practice most breaches of a reasonable opportunity to be heard result in prejudice, prejudice is not a condition precedent to relief. ${ }^{170}$

The requirements of notice and an opportunity to be heard will be discussed in sequence below, along with other circumstances which (in the peculiar situation of an abandonment hearing) may lead to a denial of a reasonable opportunity to be heard.

The abandonment hearing is normally scheduled on a peremptory basis. ${ }^{171}$ As with other proceedings before the Board, and as discussed above under the heading of failure to appear, the Board must generally notify the claimant of abandonment proceedings. While under the CRDD Rules the required "notice" was defined in terms of written notice, even the new RPD Rules require a notice of some kind (in order to make the proceedings "fair" under Rule 58(2)(a)). The potential exculpatory explanations cited above in relation to failing to attend a hearing generally apply to abandonment proceedings as well.

In order for the notice of the abandonment hearing to be meaningful, the claimant (and counsel) must understand the default in prosecution that is being alleged by the Board. Normally this is set out in the Notice to Appear for the abandonment hearing. Where the Notice to Appear mistakenly describes the default, the Board must issue a new notice or obtain the consent of the claimant (or counsel) to amend the defective notice. ${ }^{172}$ While the RPD Rules allow an abandonment proceeding to occur without written notice, the requirements of "fairness" would require that the Board explicitly inform the claimant and counsel of the default that is being considered.

Adjournments may be granted to obtain additional evidence corroborating the claimant's explanation for the alleged default. However, such adjournments are neither automatic, nor without limit. ${ }^{173}$ Despite the relative urgency of abandonment proceedings, the record must not indicate a "too-rigid and too-rushed performance by the CRDD panel." 174 In other words, the Board must not schedule an abandonment hearing in undue haste or without heeding its own directives and practice on the scheduling or adjournment of hearings. ${ }^{175}$

As with any hearing, a claimant has the right to counsel ${ }^{176}$ and the Board has an obligation to ensure that a guardian ad litem (designated representative) is appointed for any legally incapable claimant. ${ }^{177}$ The claimant (or counsel on the claimant's behalf) may make representations on the subject of abandonment and introduce evidence. Perhaps given the limited focus of the proceedings, where counsel is present but the claimant is absent the claimant can be said to have had a 
reasonable opportunity to be heard. ${ }^{178}$ However, the Board's failure to request or to consider evidence tendered or submissions of counsel will prevent a party to an abandonment hearing from having a reasonable opportunity to be heard. ${ }^{179}$

The law on natural justice and a reasonable opportunity to be heard in the context of refugee hearings generally applies to abandonment proceedings. It is unlikely that, where the circumstances are brought about or contributed to by the claimant, the Board or the Court will allow the claimant to rely upon them in order to gain relief. ${ }^{180}$ Although not an exhaustive list of possible defects, the abandonment jurisprudence suggests three common breaches of a reasonable opportunity to be heard: (i) failures of counsel; (ii) interpretation errors; and (iii) duress.

Firstly, defects in the actions of counsel can deny a claimant the reasonable opportunity to be heard. In relation to the conduct of counsel, while the jurisprudence on the denial of a reasonable opportunity at an abandonment hearing is generally equivalent to the jurisprudence of denial of natural justice more generally, the severe consequences of an abandonment hearing have caused the Court and the Board to adopt a more forgiving (at least, for the rights of a claimant) approach to the failures of counsel. ${ }^{181}$

In order to breach the requirements of natural justice, the failure of counsel must be serious enough to "deny the applicant the opportunity of a hearing." 182 For example, the failure of counsel to advise the claimant of a hearing dateespecially an abandonment date-can deny a claimant a "reasonable opportunity to be heard." ${ }^{23}$ In such a case, the claimant must have reasonably relied upon counsel ${ }^{184}$ and the failure of counsel should be unambiguous. ${ }^{185}$ However, where there is some shared fault on the part of the claimant (for example, in failing to advise the Board of an address change or in ignoring a notice sent by the Board), the courts have been reluctant to grant relief. ${ }^{186}$

Secondly, interpretation errors can vitiate a claimant's ability to present evidence and his or her right to understand the proceedings. Briefly, although interpretation defects need not be shown to prejudice the claimant in an abandonment proceeding, it must be established that a complaint concerning interpretation was made at the first available opportunity. ${ }^{187}$

Thirdly, duress can also vitiate a reasonable opportunity to be heard. The Federal Court of Appeal has held that where a person is not free to bring up facts, a reasonable opportunity to be heard has not been provided:

... that an immigration inquiry, held at a moment when the person concerned was under the direct influence of a third party (her husband) and not free to bring up facts as they were, could be seen as having breached the rules of natural justice, with the result that the decision that followed was a nullity under the Charter and the adjudicator could reconsider his decision ... ${ }^{188}$

Of course, credibility is almost always a condition precedent to the establishment of duress. ${ }^{189}$

\section{Conclusion}

The abandonment of a refugee claim is an aspect of refugee determination that has received little specific attention. However, given the seriousness of the consequences to the claimant and the general recognition of the danger of refoulement, due process guarantees should be strictly applied. In assessing the statutory structure under which abandonment decisions and the related jurisprudence are made, it would appear that the judiciary-if not the legislative or executive branches-have adopted a properly cautious approach.

It must be always remembered that the power to abandon is a discretionary decision. Although the framework of abandonment is centred around an understanding of default and a reasonable opportunity to be heard, the core of the decision is the Board's exercise of its discretion. For example, while the jurisprudence deals with abandonment in terms of a required mental intention, an alternate method of analysis is that mental intention is not a necessary element of the default but rather a factor that mitigates in favour of the Board refusing to exercise its discretion to abandon a refugee claim notwithstanding a default. A similar argument can be made that some of the unusual cases regarding the definition of a reasonable opportunity to be heard can be better understood as instances where a reasonable opportunity was given but other circumstances mitigated against the exercise of discretion.

Understanding the issue of abandonment as the exercise of discretion also places renewed focus on its boundaries: those imposed by the statute, the principles of the rule of law, the principles of administrative law, the fundamental values of Canadian society, and the principles of the Charter. ${ }^{190}$ The most significant boundary in the case of refugee claims facing abandonment is the internationally accepted understanding that bona fide refugees should never be refused protection, even if there has been non-compliance with various administrative rules. As the High Commissioner himself noted in a recent address to ExCom:

While UNHCR supports measures to combat misuse of asylum systems, I am concerned that in some cases indiscriminate measures have led to non-admission, denial of access to asylum procedures, and even incidents of refoulement. ${ }^{191}$ 
Ultimately it is this denial of access and danger of refoulement that must inform abandonment proceedings and decisions.

\section{Notes}

1. Personal email correspondence with the Canadian Council for Refugees dated 7 September 2008 (on file with author).

2. Ibid. Referring to the Central Canada offices of the Board. The variation between offices of the Board has declined significantly; in 2001 almost one-quarter of claims before the Vancouver office of the Board were declared abandoned (against a national average of 10 per cent). Immigration and Refugee Board, Immigration and Refugee Board Statistics for 2001: Convention Refugee Determination Division (Ottawa, February 2002).

3. In previous years, almost a quarter of claims made against China and India were declared abandoned.

4. United Kingdom Asylum Statistics 2007 (Home Office Statistical Bulletin, November 2008) Table 4.2 at 40. Noncompliance rates vary between country of origin with EU Accession States (18 per cent) and China (40 per cent) being the top countries of origin for non-compliance.

5. UNHCR "UNHCR Position on the Return of AsylumSeekers to Greece under the Dublin Regulation" (15 April 2008)

6. 28 July 1951, 189 U.N.T.S. 150, Can. T.S. $1969 / 6$ (entered into force 22 April 1954, accession by Canada 2 September 1969) [Refugee Convention\}.

7. UNHCR, Handbook on Procedures and Criteria for Determining Refugee Status under the 1951 Convention and the 1967 Protocol relating to the Status of Refugees HCR/IP/4/ Eng/REV.1 (1979) (UNHCR 1979) (Reedited, January 1992) (the UNHCR Handbook) at 28.

8. Most claimants in Canada are eligible to have their refugee claims determined by the RPD. A small number of claimants are eligible to have their refugee claims determined by a Pre-Removal Risk Officer of the Ministry of Citizenship and Immigration. This paper will focus on the former process insofar as it involves the overwhelming majority of refugee claimants and has, as a possible outcome, abandonment. For a more detailed discussion of the alternative processes by which a refugee claim can be determined (and an enumeration of the claimants to which such processes apply, see Martin Jones and Sasha Baglay, Refugee Law (Toronto: Irwin Law, 2007), c. 2 and 8.

9. See Francis v. The Queen, [1956] S.C.R. 618, at 621; Capital Cities Communications Inc. v. Canadian Radio-Television Commission, [1978] 2 S.C.R. 141, at 172-73.

10. Baker v. Canada (M.C.I.), [1999] 2 SCR 817 at para. 69.

11. The "right to asylum" is used as shorthand for the right to protection against return to a country in which a person would face persecution. The description of this protection as a "right" is not without controversy; it is never described as such in treaty law and the only treaty with such a provi- sion died on the drafting table. Nonetheless, it is used here for the sake of brevity in lieu of the longer locution of "the right to enjoy a prohibition upon forced return to the state in which one would risk persecution as a refugee."

12. Including Article 14 of the Universal Declaration of Human Rights; Article 1 of the Declaration on territorial Asylum; and Article 22(7) of the American Convention on Human Rights.

13. 606 U.N.T.S. 267, entered into force 4 October 1967.

14. Paragraph 189 of the UNHCR Handbook, supra note 7.

15. The silence of the Refugee Convention and the Protocol on the appropriate methods of refugee status determination does not in any way imply that the implementation of appropriate methods is not fundamental to both instruments: "Whilst the instrument may not provide expressly for determination of refugee status, such a determination is nevertheless an inherent requirement." UNHCR Executive Committee Sub-Committee on International Protection Note on Determination of Refugee Status under International Instruments, 24 August 1977 (SCIP EC/SCP/5).

16. For example, see the right of association (Article 15, "refugees lawfully staying"), to the right to self-employment (Article 18, "refugees lawfully present"). The leading treatise on the linkage between refugee rights and their status ("attachment") to their country of asylum is James Hathaway's magnum opus: The Rights of Refugees under International Law (Cambridge: Cambridge University Press, 2005).

17. The term "bona fide refugee" is used throughout this paper to indicate a refugee claimant who is in fact (not withstanding any finding by a court or administrative body to the contrary) within the definition of Convention refugee set out in the Convention. While the term "refugee" could also be used, the term bona fide refugee is used to avoid any confusion with "refugee claimant" and an individual (who may or may not be a bona fide refugee) who has been determined by an administrative body to be deserving of protection as a refugee.

18. Articles 32 and 33 of the Convention allow for expulsion and refoulement only on grounds of, respectively, national security or public order; and danger to the security or community of the country of refuge. See also Hoang v. Canada (M.E.I.) (1990), 13 Imm. L.R. (2d) 35 (F.C.A.) at para. 41.

19. Chan v. Canada (M.E.I.) [1995] 3 S.C.R. 593 at para. 46.

20. Paragraphs 192(ii) and 198 of the UNHCR Handbook and Addendum to the Report of the United Nations High Commissioner for Refugees: Report of the Twenty-Eighth Session of the Executive Committee of the High Commissioner's Programme, General Assembly Official Records: Thirty-Second Session, Supplement No.12A (A/32/12/Add.1) (1977).

21. UNHCR's observations on the European Commission's proposal for a Council Directive on minimum standards on procedures for granting and withdrawing refugee status (COM[2000] 578 final, 20 September 2000) UNHCR (Geneva, July 2001). 
22. Fourth Periodic Reports of States Parties Due In 1995: Canada CCPR/C/103/Add.5. (State Party Report) (15 October 1997).

23. See the European Court of Human Rights decisions on a similarly worded provision in Xv UK (App 3325/67) (1967) 10 YB 528 and Agee v. UK (App 7729/76) (1976). More recently, the UN Human Rights Committee appeared willing to revisit the issue in $A v$. Australia (Communication 560/1993) (1997). However, while an Article 14 complaint was deemed admissible with respect to a complaint concerning refugee determination and other immigration proceedings, on the facts no determination was made on the merits.

24. An exception to these procedural protections is allowed "where compelling reasons of national security otherwise require."

25. The use of Article 13 presupposes that an RSD decision is a decision relating to expulsion. In Canadian law, the effect of RSD on expulsion is more ambiguous. Generally, under s. 49(2) of the IRPA, a negative RSD decision (including an abandonment decision) simply causes an underlying conditional removal order to become effective and enforceable. While abandonment decisions are not directly decisions to "expel" it can be argued that under the doctrine of reasonable foreseeable consequence an abandonment hearing, as an immediate trigger of removal proceedings, is an act within the purview of safeguards concerning expulsion.

26. David Mattas, "Fairness in Refugee Determination" (Oxford Symposium on Refugees, 19 August 1985) [revised] at 2.

27. The seriousness of the consequences of a decision (i.e. in the case of refugee proceedings and capital trials, respectively, refoulement and execution) has been cited as a factor in determining the appropriate procedural standards: Gargano v. Canada (Minister of Employment and Immigration) (1994), 85 F.T.R. 49; Baker v. Canada (Minister of Citizenship and Immigration), [1999] 2 S.C.R. 817. The consequences of an erroneous refugee decision have, in the policy literature, been described more euphemistically as "grave" and "potentially life-threatening." The tragic irony of RSD, and the underlying point of view of this article, is that despite such severe consequences the procedural entitlements of a refugee claimant are relatively minimal.

28. Inter-American Court of Human Rights Advisory Opinion OC-16/99, The Right to Information on Consular Assistance in the Framework of the Guarantees of the Due Process of Law at 70 (paras 135-136), 1 October 1999 as requested by the United Mexican States.

29. See Taher v. M.C.I. [2002] F.C.T. 991.

30. Rahaman v. M.C.I. [2002] F.C.A. 89.

31. "Only when faced with completely unequivocal statutory language should the Court conclude that an Act of Parliament derogates from international norms respecting the protection of human rights." per Rahaman, ibid.

32. "Determination of Refugee Status" UNHCR Executive Committee Conclusion No. 8 (XXVIII) (12 October 1977).
33. UNHCR, Procedural Standards for Refugee Status Determination under UNHCR's Mandate (September 2005) at $\$ 9.1$.

34. Ibid. at $\$ 9.2$.

35. Council Resolution of 20 June 1995 on Minimum Guarantees for Asylum Procedures, Official Journal C 274, 19 September 1996

36. Article 12 of the Council Directive 2005/85/EC of 1 December 2005 on minimum standards on procedures in Member States for granting and withdrawing refugee status Official Journal L 326, 13/12/2005 13 (the EU Procedural Directive).

37. Article 12(a).

38. Article 12(b).

39. Article 12(c). This provision applies only to a very limited number of claimants who have made claims for refugee protection where the information they have already provided indicates that (i) the claim is unfounded due to the claimant being from a country declared to be a safe country of origin or a safe third country of transit (Article 24(4) (c)); (ii) the claimant has been "clearly unconvincing" in his or her claim (Article 24(4)(g)); the applicant has previously been denied protection and has submitted a new application which does not raise new evidence (Article 24(4)(h)); and the application is merely in order to frustrate a removal decision (Article 24(4)(j)).

40. Article 20(1)(a). The right to reopen requires establishing that "his/her failure [to attend an interview] was due to circumstances beyond his control."

41. Beyond consideration of a refugee claim by the RPD of the Board, the IRPA provides two other possible avenues of risk assessment for refugees (in addition to another applicable immigration-related applications). Firstly, the IRPA (ss. 112-114 and ss. 160-174 of the Immigration and Refugee Protection Regulations [SOR/2002-227] [the IRPA Regulations]), a pre-removal risk assessment [PRRA] can be requested by most individuals who have been refused refugee protection before their removal from Canada. The PRRA is performed by an immigration officer, does not normally involve a hearing or interview, and uses short limitation periods (all submissions and evidence are due within thirty days of notification). As a result, the success rate in PRRA applications is about 2 per cent. The UN Committee Against Torture has criticized the PRRA procedural protections, most recently in its decision in the matter of Communication 2006/927: Sogi v. Canada UN CAT/C/39/D/297/2006 (esp. at 10.5). Both The second avenue of risk assessment is (under the provisions of the IRPA s. $110 \mathrm{~g}$ ) an appeal to the Refugee Appeal Division of the Board. Unfortunately, the statutory provision in question is not currently in force and individuals declared to have "no credible basis" and who have "abandoned" their claims are not allowed such an appeal.

42. It would be more appropriate to consider refugee claimants facing abandonment procedures as potentially "unco- 
operative" claimants as opposed to "fraudulent" claimants. Unfortunately, the UNHCR has provided limited guidance on the consequences for such uncooperative claimants and there is very little other international guidance on the subject. See the UNHCR Handbook at para. 205 generally.

43. UNHCR Position on Manifestly Unfounded Applications for Asylum (UNHCR, Geneva, December 1992)/

44. R.S. 1985, c. I-2.

45. 28 June 2002 was the date on which the Immigration and Refugee Protection Act, the successor legislation to the Immigration Act, came into effect.

46. Although the Immigration and Refugee Board was established on 1 January 1989 by the Refugee Act, the CRDD in the form discussed in this paper (including the abandonment provisions of s. 69.1) did not come into force until 1 February 1993 by virtue of 1992, c. 49. The CRDD Rules discussed in this paper came into force on the same date.

47. 2001, c. 27.

48. Immigration Act, ss. 28(2)(b) and 32.1(6)(b); IRPA, s. 49(2) (d).

49. IRPA, s. $101(1)(\mathrm{c})$, s. $112(2)(\mathrm{d})$.

50. Immigration Act, ss. 69.1(6).

51. Immigration Act, s. 69.1(6)(a).

52. The PIF is a ten-page questionnaire canvassing the claimant's biographical details, education, past employment, residential history, travel abroad, documents, and basis of claim. It is the primary document in the Board's assessment of a refugee claim. Immigration Act, s. 69.1(6)(b) via s. 46.03(2) and Rule 14(1) of the Convention Refugee Determination Rules (CRDD Rules) SOR/93-45.

53. Immigration Act, s. 69.1(6)(c).

54. Rules 14(2) and 35(4) of the CRDD Rules.

55. Chairperson's Practice Notice: Timely Filing of Personal Information Forms (PIF's) (5 May 1998).

56. Ibid.

57. Immigration Act, s. 69.1(6).

58. Rule 32(2) of the CRDD Rules further required the Board to advise a refugee claimant that, if their claim was not abandoned after the abandonment hearing, the Board "will forthwith commence or resume the hearing into the claim or application." While this requirement was met on the Board's standard notices of abandonment hearing, it was not the Board's routine practice to immediately proceed into the hearing of a claim after setting aside the abandonment issue.

59. Rule 39 of the CRDD Rules.

60. Rule 40 of the RPD Rules.

61. The other divisions of the Board, the Immigration Division and the Immigration Appeal Division, deal with the issuance of removal orders, the revocation of permanent resident status, and appeals of removal orders and revocations of statuses.

62. See Rules 3 to 5 of the RPD Rules.

63. Rule 4(1) of the RPD Rules.

64. Rule 4(4) of the RPD Rules.
65. Rule 5 of the RPD Rules, specifically Rule 5(1), states: “The claimant must complete the Personal Information Form and sign and date the included declaration ..."

66. Rule 14(1) of the CRDD Rules states "A person concerned shall provide the Refugee Division with information respecting the claim ..."

67. The Oxford English Dictionary, 2d ed., defines "request" as (in part): "The act, on the part of a specified person, of asking for some favour, service, etc.; the expression of one's desire or wish directly addressed to the person or persons able to gratify it."

68. Sections 170 (b), (c), and (e), respectively, of the IRPA. As with the EU Procedural Directive, s. 170(f) provides for no hearing where a claim is accepted (under the "expedited hearing" program of Rule 19 of the RPD Rules).

69. Rule 58(2) of the RPD Rules.

70. Rule 58(2)(a) of the RPD Rules. However, it is unlikely to be fair to proceed in such a manner where the claimant is without counsel: Mani v. Canada (Minister of Citizenship and Immigration), 2004 FC 376.

71. The exception, under Rule 58(1) of the RPD Rules, is where the claimant has not filed his or her PIF within the prescribed period and neither the RPD, nor the Minister, nor counsel for the claimant, is aware of the contact information of the claimant.

72. Section 161(1)(b) is cited at least insofar as the waiver of a hearing may be seen as a consequence of failing to provide the Board with the address information required by Rules $4(1)$ and (2).

73. René Dussault and Louis Borgeat, Administrative Law: A Treatise, $2 \mathrm{~d}$ ed., vol. 1, trans. by Murray Rankin (Toronto: Carswell, 1985) [Dussault and Borgeat] at 364-365.

74. For an example of the impact of an explicit statutory power to provide for exceptions in statutory instruments on the determination of whether a statutory instrument is ultra vires see Telecommunication Workers Union et al. v. British Columbia Telephone Company, Canadian Telephone \& Supplies Ltd. [1985] 1 S.C.R. 840.

75. Dussault and Borgeat at 435 , quoted sympathetically in the judgment of Dube J. of the Federal Court Trial Division in Canada v. St. Lawrence Cruise Lines Inc. [1996] 2 F.C. 371.

76. In the context of municipal law see Re: Bunce and Town of Coburg, [1963] 2 O.R. 343 (C. A.).

77. The French-language text of s. 170(b) states that the RPD must "dispose de celle-ci par la tenue d'une audience" [dispose of it by the holding of a hearing].

78. See, for example, s. 173(a) which provides for only a qualified ("where practicable") requirement for a hearing before the Immigration Division and s. 171 which does not provide for a hearing before the Refugee Appeal Division.

79. The Immigration Act treats the right to hearing with more ambiguity, dealing with it in passing and in an explicitly qualified manner. Section 69.1(1) requires the Board to "commence a hearing into the claim" as soon as practicable. Section 69.1(6) limits the Board to simply the provision of 
"a reasonable opportunity to be heard" in abandonment proceedings.

80. See Bill C-31, s. 165(b). Note the substantive changes between that provision and s. 170(b) of the IRPA related to the inclusion in IRPA of teleconferencing provisions (s. 164 of the IRPA) and the shift of the provision of notice to its own subsection (s. 170(c) of the IRPA).

81. See Canada Gazette, Part I, Vol. 135, No. 50 (9 December 2001) at 4702 et seq. (Note: Rule 58 was numbered Rule 59 in the first prepublication.)

82. [1991] 3. S.C.R. 349 (L'Heureux-Dube, in dissent-although not on this point).

83. See Singh et al. v. M.E.I. [1985] 1 S.C.R. 177 at 200 (per Wilson J.).

84. Subsections 3(1)(b), (c), and (e), respectively.

85. 1960, c. 44.

86. Singh v. M.E.I., [1985] 1 S.C.R. 177.

87. See Baker v. M.C.I. [1999] 2 S.C.R. 817.

88. Suresh v. Canada (M.C.I.), [2002] SCC 1.

89. Duke v. The Queen, [1972] S.C.R. 917 at 923 [emphasis added].

90. [1990] 2 S.C.R. 1324.

91. For example, in the matter of Soto Ibacache v. M.C.I. IMM 4244-96 (Tremblay-Lamer J.) the Court approved of the Board's failure to serve the claimants (who had not provided the Board with an address) with a notice to appear for an abandonment hearing. While it may be true, as the Court states, "no one is bound to do the impossible," the holding of hearing is not an impossible act. Notwithstanding the anticipated absence of a claimant, the Board may nonetheless convene a hearing-especially when counsel has been retained.

92. Section $162(2)$ of the IRPA.

93. Rule 58(3) of the RPD Rules,

94. What were formerly "motions" under the CRDD Rules are now "applications" under the RPD Rules. Notwithstanding the change in terminology, the term "motion" has been employed in this paper to maintain consistency.

95. Kabir v. M.C.I. [2001] F.C.T. 1267 (Nadon J.).

96. The jurisprudence documents a haphazard array of remedies-ranging from a de novo abandonment hearing to a hearing on the merits of the claim to a "new hearing on reinstatement."

97. Immigration Act, s. 82.1(1) and (3); IRPA, s. 72(2)(b).

98. Cortez v. M.C.I. [2001] FCT 1197 (Nadon J.).

99. Valenzuala Barrientos v. M.C.I. IMM 2481-96 (Noel J.).

100. Kastrati v. Canada (Citizenship and Immigration), 2008 FC 1141. Even before the recent decision of the Supreme Court of Canada mandating such an approach in Dunsmuir $v$. New Brunswick, 2008 SCC 9, the Court generally applied the standard of reasonableness simpliciter to abandonment decisions: Forgacs v. M.C.I. [2001] F.C.T. 235 (Blais J.). This standard has also been described as that of "serious scrutiny" per Lemieux J. in Ahmad v. M.C.I. IMM 5626-98.
101. Ou v. M.C.I. IMM 5559-97 (McGillis J.). For an opinion distinguishing $\mathrm{Ou}$ see Iantbelidze v. M.C.I. [2002] F.C.T. 932 (Heneghan J.).

102. Stumf et al. v. M.C.I. IMM 5975-99 (Simpson J.).

103. However, a judicial review application of the denial of a motion to reopen can only be based upon defects in the Board's analysis of the motion and not the correctness of the underlying abandonment decision: Kononov v. MCI [1999] F.C.J. No. 1121; Diraviam v. Canada (Minister of Citizenship and Immigration), 2004 FC 1470; Ali v. MCI 2004 FC 1153; although, the Court entertains the possibility of a contrary view in Vranici v. Canada (Minister of Citizenship and Immigration), 2004 FC 1417.

104. Powar v. M.C.I. IMM 365-99 (Teitelbaum J.).

105. See Angle v. Minister of National Revenue, [1975] 2 S.C.R. 248 generally for the doctrine of "issue estoppel" which prohibits renewed litigation where (i) the same question has been decided; (ii) the decision was final; and (iii) the parties in both proceedings are the same. However, an exception to "issue estoppel" may be made in the (unlikely) event that new evidence becomes available between the judicial review of the abandonment decision and the subsequent judicial review of the denial of the motion where the much quoted conditions laid out in Fenerty v. The City of Halifax (1920), 50 D.L.R. 435 at 437-438 (N.S.S.C.) are met. The Court has issued conflicting opinions depending on the order in which judicial review is pursued: in Lin $v$. Canada (Minister of Employment and Immigration), [2005] F.C.J. No. 634 (judicial review of the abandonment decision first) the Court held a subsequent judicial review application to be res judicata whereas in Xu v. Canada (Minister of Citizenship and Immigration), 2006 FC 718 (judicial review of the reopening decision first) the Court held a subsequent judicial review application not to be completely barred by res judicata.

106. CRDD V97-00999 (Jackson, 9 September 1999).

107. Rule 55(4). While the wording of Rule 55(4) does not preclude motions to reopen being granted on other grounds, the Court has interpreted the provision as providing the sole ground for reopening. See Wackowski v. Canada (Minister of Citizenship and Immigration), [2004] F.C.J. No. 315 (F.C.) at 12 and Ali v. Canada (Minister of Citizenship and Immigration), $2004 \mathrm{FC} 1153$ at 24.

108. Forgacs v. M.C.I. [2001] F.C.T. 235 (Blais J.). In CRDD V9000988 (Groos, Robles, 8 September 1992) the Board allowed an almost three-year delay where " $[u]$ ntil recently, all contacts which the claimant apparently had with immigration officers would suggest to any reasonably well-informed observer that his refugee claim remained outstanding despite the decision that he had abandoned his claim."

109. CRDD T96-01786 (Sarzotti, 29 August 1996).

110. The leading case on the Board's power to reopen hearings where natural justice has been denied is Gill v. Canada (M.E.I.), [1987] 2 F.C. 425 (C.A.). 
111. Rojas Rojas v. M.C.I. [2002] F.C.T. 802 (Dawson J.). Although the Minister must be served with the notice of motion, a review of the Board's jurisprudence indicates it is rare for the Minister to actively oppose a motion.

112. See Key Point Guide to Refugee Law for CRDD Members (Legal Services, Immigration and Refugee Board, November 2000) at 46: "The standard of proof with respect to the determination of facts is the civil standard of balance of probabilities." See also Note on Burden and Standard of Proof in Refugee Claims (UNHCR, Geneva, 16 December 1998) at para. 8.

113. CRDD M99-11272 (Pergat, 10 April 2001).

114. See Wydrzynski v. M.C.I. IMM 1002-00 (Heneghan J.). In addition, arguably the Federal Court has no jurisdiction to grant interlocutory relief unless there is an underlying application for judicial review before the Court.

115. CRDD TA0-11584 (Rucker, 30 January 2002).

116. CRDD U92-02932, U93-03410 (Smith, 26 April 1994).

117. The provision of such an endorsement has been found to comply with both the statutory requirements of the IRPA and common-law requirements of procedural fairness: Ali v. Canada (Minister of Citizenship and Immigration), 2004 FC 1153. However, such an endorsement must nonetheless provide a "meaningful" justification of the decision: Javed $v$. Canada (Minister of Citizenship and Immigration), 2004 FC 1458.

118. In addition, since the coming into force of the IRPA both the overall number of claimants and the number of decisions per year have decreased substantially. There has also been a concurrent reduction in the availability of legal aid to seek judicial review in most provinces which has likely reduced the number of review applications before the Federal Court. On the effect of this latter issue, see Austin Lawrence and Pauline de Jong A Synthesis of the Immigration and Refugee Legal Aid Research (Department of Justice, 2006).

119. Liyanagamage v. Canada (Secretary of State) (1994), 176 N.R. 4 (F.C.T.D.).

120. Given the clear statutory language in both the Immigration Act and the IRPA it is perhaps more accurate to state that such actions can constitute defaults but that, given that the power to abandon is discretionary in nature, the Board should not declare a claim to be abandoned unless there is an accompanying mental guilt. See the conclusion (below) for an elaboration of this point.

121. For an example of an extraordinary tale (of abduction causing a failure to appear) that was not believed see CRDD V97-03027 (Jackson, 11 August 1999).

122. The Board must consider "the full picture of the course of conduct" per Clavijo Albarracin v. Canada (Citizenship and Immigration), 2008 FC 1143.

123. Ahmad v. M.C.I., supra note 100.

124. CRDD T96-01671, T96-00204, T96-00205 (Morrison, Okhovati, 23 May 1997)

125. IMM 4351-98.
126. Levieva et al. v. M.C.I. [2002] F.C.T. 163 (Dawson J.).

127. The jurisprudence's consistently followed pattern of determining the issue of abandonment before considering the merits of the claim seems to suggest that the latter will not be considered in determining the former.

128. Ghassan v. M.E.I. IMM-2843-93 (Denault J.); Abdelhar v. M.C.I. IMM 5253-97 (Blais J.); CRDD M94-05728, M9405729, M94-05730 (Boisrond, Longchamps, 5 March 1996).

129. Atwal v. M.C.I. IMM 791-98 (Simpson J.).

130. See the Board's actions described in the Court's judgment in Levieva et al. v. M.C.I. [2002] F.C.T. 163 (Dawson J.).

131. The Minister serves a claimant with the PIF under s. 100(1) of the IRPA and Rule 3(1) of the RPD Rules (previously s. 46.02 of the Immigration Act and Rule 6(1)(c) of the CRDD Rules).

132. The latter has been proven through the use of the postmark on the envelope in which the PIF is mailed to the claimant by the Ministry. See Rakrouk v. M.C.I. [2001] F.C.T. 258.

133. Cirahan v. M.C.I. IMM 1650-97 (Muldoon J.) (in the context of an application for a stay of removal pending judicial review of the abandonment decision).

134. Obiter dicta in CRDD VA1-01901 (Jackson, 9 April 2002).

135. CRDD V99-00687 (Jackson, French, 24 June 1999).

136. RPD VA2-01049 (Jackson, 16 July 2002); for a different conclusion see CRDD VA1-02258 (Jackson and Gibbs, 22 October 2001).

137. Chairperson's Practice Notice on the Timely Filing of Personal Information Forms (PIFs) (5 May 1998) and Commentary on RPD Rules-Rules 5 and 6.

138. Perez Lopez v. M.C.I. IMM 5716-99 (Teitelbaum J.).

139. Rahman v. Canada(Minister of Citizenship and Immigration), 2005 FC 430; Tajadodi v. Canada (Minister of Citizenship and Immigration), 2005 FC 1096.

140. CRDD M93-06035 (Jumelle, Lavoie, 6 September 1993); CRDD V99-00687 (Jackson, French, 24 June 1999). However, for an opposite position see Masood v. Canada (Minister of Citizenship and Immigration), 2004 FC 1224.

141. CRDD Handbook (Immigration and Refugee Board, 31 March 1999) at 17-4 quoted with approval in CRDD T9805059 (Stanwick, Cram and Bubrin, 22 December 2000).

142. Powar v. M.C.I. IMM 365-99 (Teitelbaum J.) quoting Aubut v. Minister of National Revenue 126 N.R. 381 at 383 (F.C.A.) with approval.

143. See the rather unusual facts of Atwal v. M.C.I. IMM 791-98 (Simpson J.) in support (albeit in obiter dicta) of this proposition. Notwithstanding such a usual presumption, the disappearance of the claimant in the midst of the hearing, like any other event, must be judged in the context of all the circumstances of the case per CRDD T96-01671, T9600204, T96-00205 (Morrison, Okhovati, 23 May 1997).

144. The Board is advised by the Ministry upon the referral of the matter (i) the method of service of the PIF by the Ministry, and (ii) the current address (if known) of the claimant. See CRDD VA1-01901 (Jackson, 9 April 2002) for a 
case where the abandonment was set aside when the Board failed to take note of this information.

145. Ou v. M.C. I. IMM 5559-97 (McGillis J.); Zaouch v. M.C.I. IMM-3051-95 (Richard J.) ; Rodriguez v. Canada (Minister of Citizenship and Immigration), 2005 FC 629.

146. Hurtado Izauierdo v. M.C.I. IMM 4695-97 (Rouleau J.).

147. CRDD T93-12255 (Sarzotti, 3 March 1998).

148. CRDD V96-01897 (Robles, Brisson, 26 March 1998).

149. Mussa v. M.E.I. IMM-6043-93 (18 July 1994) quoted sympathetically in CRDD TA0-11584 (Rucker, 10 January 2002); see also CRDD V96-01387 (Robles, 12 March 1997) where a claimant was found to be under a duty to notify the Board of address changes even after the Board lost (albeit temporarily) jurisdiction over the matter.

150. Cavus v. M.C.I. IMM-4494-98 (Nadon J.).

151. Escorcia Trejo v. Canada (Citizenship and Immigration), 2008 FC 1207.

152. Bello Perez v. S.G.C. IMM-5662-93 (Joyal J.),

153. CRDD V93-02255 (Neuenfeldt, 25 October 1994).

154. CRDD U97-01304 (Bubrin, Sarzotti, 1 November 1999).

155. CRDD T96-01786 (Sarzotti, 29 August 1996).

156. CRDD TA0-11584 (Rucker, 10 January 2002).

157.CRDD M95-04338 (Singer, Colavecchio, 7 November 1996).

158. See also CRDD U96-04629 (MacAdam, Wright, 13 January 1998).

159.CRDD M96-02461 (Handfield, Ndejuru, 4 November 1997).

160. Thurairajah et al. v. M.C.I. IMM 6083-99 (O’Keefe J.).

161. Levieva et al. v. M.C.I. [2002] F.C.T. 163 (Dawson J.).

162. Kabari v. M.C.I. IMM 1095-99 (Pinard J.).

163. CRDD U96-04629 (MacAdam, Wright, 13 January 1998); CRDD T96-01035 (Sarzotti, 3 April 1998).

164. Pilnitz v. M.C.I. IMM-1205-96 (Tremblay-Lamer J.); Dadi v. M.C.I. IMM-4195-98 (Pinard J.).

165. CRDD TAO-03876 et al. (Eustaquio, Antemia, 14 August 2000); CRDD T96-01671 (Morrison, 7 November 1997); CRDD M95-02129 (Roussy, Dionne, 20 November 1996).

166. CRDD M93-03537 (La Salle, Marien-Roy, 26 October 1995); Gapchenko v. Canada (Minister of Citizenship and Immigration), 2004 FC 427; Davila Ruiz v. Canada (Citizenship and Immigration), 2008 FC 915.

167. CRDD U97-00975 (Wright, MacAdam, 25 February 1998).

168. This must include, where appropriate, considering allowing the claimant to present evidence "otherwise than by personal appearance" (i.e. through tele- or video-conferencing technology). Sundaram v. Canada (Minister of Citizenship and Immigration), 2006 FC 291.

169. Gulishvli v. M.C.I. [2002] F.C.T. 1200 (Kelen J.).

170. Kabir v. M.C.I. [2001] F.C.T. 1267 (Nadon J.).

171. The setting of abandonment hearings on this basis does not constitute a violation of natural justice: Enahoro v. Canada (Minister of Citizenship and Immigration), 2006 FC 430.
172. Kavunzu v. M.C.I. IMM 4351-98 (Nadon J.) This case was decided under the more restrictive CRDD Rules; the RPD Rules now provide that written notice is not always required.

173. CRDD M93-10303 (Yassini, Champoux Ohrt, 1 March 1995).

174. Cirahan v. M.C.I. IMM-1650-97) (Muldoon J.).

175. Zulquerain v. M.C.I. IMM 751-00 (O’Keefe J.).

176. The discussion above on the limits to the right to counsel is applicable to the right to counsel at abandonment hearings.

177. Stumf et al. v. M.C.I. [2002] F.C.A. 148 (Sharlow J.A. per coram).

178. Bello Perez v. S.G.C. IMM-5662-93 (Joyal J.).

179. Ding v. M.C.I. IMM 3149-99 (Campbell J.); Rojas Rojas [2002] F.C.T. 802 (Dawson J.).

180. Bhullar v. M.C.I. IMM 1862-99 (Pinard, J.)

181. Mahood v. Canada (Minister of Citizenship and Immigration), [2000] F.C.J. No. 1480; Muqeem v. Canada (Minister of Citizenship and Immigration), 2005 FC 465.

182. Shirwa v. Canada (M.E.I.), [1994] 2 F.C. 51 (T.D.) at 60-61 (Denault J.).

183. Ahmad v. M.C.I., supra note 100.

184. The language abilities (or lack thereof) are frequently a reason cited in support of the reliance by a claimant upon counsel.

185. Taher v. M.C.I. [2002] F.C.T. 991 (Pinard J.).

186. Contributory negligence will remove the ability of a claimant to benefit from the mistake of counsel: Masood v. Canada (Minister of Citizenship and Immigration), 2004 FC 1224.

187. Mohammadian v. M.C.I. IMM-6500-98 (Pelletier, J.); See also Iantbelidze v. M.C.I. [2002] F.C.T. 932 (Heneghan J.) for interpretation problems in the context of abandonment proceedings.

188. Longia v. Canada (M.E.I.), [1990] 3 F.C. 288 (C.A.) at 294 (referring to Kaur v. Canada (M.E.I.), [1990] 2 F.C. 209 (C.A.) with approval).

189. CRDD V97-03027, supra note 121.

190. See Baker, supra note 10. .

191. UNHCR Opening Statement by Mr. Ruud Lubbers, United Nations High Commissioner for Refugee at the Fifty-third Session of the Executive Committee of the High Commissioner's Programme (30 September 2002),

Martin Jones is a research associate at the Centre for Refugee Studies and the Managing Editor of Refuge. He previously practiced refugee law, regularly representing individuals in abandonment proceedings. 